Александар МИЛАНОВИЋ

Универзитет у Београду

Филолошки факултет

\title{
АНГЛИЦИЗМИ У СРПСКОМ ЈЕЗИКУ ПРЕДВУКОВСКОГ ПЕРИОДА
}

1. Нема никакве сумње да је и српски језик, попут других језика на тлу савремене Европе, данас под веома јаким утицајем енглеског, што се огледа и у готово неконтролисаном продору англицизама, о чему постоји бројна и јако добра србистичка литература. ${ }^{1}$ Знамо да је и током читавог 20. века, а нарочито у његовој другој половини, енглески језик преко англосаксонске културе и цивилизације мењао и обогаћивао лексику српског језика, али је мање истражено колики је био његов утицај у 18. и првој половини 19. века. Тај период обично се у србистици назива „предвуковским" (Михајловић 1972 и др.), будући да су у њему функцију књижевног језика вршили рускословенски и славеносрпски језик, идиоми који су кроз време међусобно били у односима конкуренције и коегзистенције (Толстој 2004). У овоме периоду писало се још и на српском народном језику, па се све до Вукове књижевнојезичке реформе, у време доминације класицизма у српској књижевности и култури, може судити о прихватању античке концепције трију стилова (Павић 1979, Павић 1983, Павић 1985). Према њеним поставкама, српском народном језику припадала је функција ниског стила, славеносрпском језику - средњег, а рускословенском језику - високог.

Наведени језички идиоми били су у различитој мери отворени за стране језичке утицаје. Рускословенски језик, тј. старословенски језик у руској редакцији, био је, наравно, захваљујући својој богослужбеној функцији сасвим затворен за продор нових речи странога порекла. У славеносрпски језик - хибридни идиом настао посрбљавањем рускословенског - речи

${ }^{1}$ В. бројне радове и студије Твртка Прћића. 
страног порекла продирале су брзо и лако (Милановић 2010, Милановић 2013, РС 2017), и то како оне које су стизале културним контактима тако и оне које су већ постојале у народном језику. То је управо и омогућавала функционална поливалентност славеносрпског језика: њиме су писана књижевна дела, али и дневне новине, часописи, научне расправе, административно-правни документи и др. Развој публицистике условио је потребу за именовањем многих нових предмета и појава у српском језику, а нове речи странога порекла продирале су и као последица развоја различитих научних дисциплина, и то првенствено у функцији научних и стручних термина.

Српска триглосија коначно је напуштена у време романтизма, када је функцију књижевног језика преузео нови идиом са народним језиком у основици, данас обично именован као вуковски. И он је, међутим, остао отворен за стране језичке утицаје, лишен јачег језичког пуризма, о чему сведоче и круцијална Вукова дела почев од првог Српског рјечника (1818), преко превода Новог завјета (1847), па све до другог Српског рјечника (1852).

2. Захваљујући одговарајућем социолингвистичком контексту (школовање младих на немачким универзитетима, утицај немачке технике и технологије, доминација немачког романтизма у књижевности и филозофији итд.), у предвуковском периоду несумњиво је најснажнији био утицај немачког на српски језик, па је једна од кључних Вукових замерки славносрпским писцима била констатација да им је израз искварен бројним германизмима. Током читавог 19. века интелектуалци вуковске оријентације водили су интензивну борбу око протеривања непотребних лексичких и синтаксичких германизама из српског књижевног језика.

Утицај енглеске културе био је све до средине 19. века неупоредиво мањи. ${ }^{2}$ Занимљиво је, али и у доброј мери индикативно, да до сада нису рађена обимнија истраживања утицаја енглеског језика на српски у 18-19. веку. Овакво истраживање морало би стога у будућности подразумевати све фазе, почев од ексцерпирања грађе, а корпус би морао бити и стилски раслојен, тј. формиран на грађи коју би чиниле дневне новине, часописи, научне расправе, административно-правни документи, пословна и лична преписка, дневници и мемоари итд. Јасно је да ово нису истраживачки задаци за појединца, већ за институцију.

Постојећи историјски речници, попут Речника ЈАЗУ, у оваквом истраживању би били само додатна и контролна литература будући да им извори нису сасвим релевантни. Тако су, на пример, за Речник ЈАЗУ из превуковске епохе ексцерпирана само књижевна дела Доситеја Обрадовића, Захарија Орфелина, Јована Рајића и Аврама Максимовића

\footnotetext{
${ }^{2}$ В. нпр. расправе Лазе Костића о преводима са енглеског језика.
} 
(Михајловић 1972: III), и то углавном она писана народним језиком или славеносрпским језиком у својој развијенијој фази, у којој је максимално посрбљен на граматичком плану, а који данас називамо доситејевским језиком. Уз то, дела публицистичког и научног садржаја уопште нису ушла у корпус, што се одмах одразило на веродостојност података у речнику: „У Речнику JАЗУ, на пример, не налазимо тако обичне речи као што су адвокат, администратор, администрација, барометар, биографија и сл." (Михајловић 1972: III).

3. Један од ретких речника који пружа индикативне информације о првим англицизмима у српском језику јесте Грађа за речник страних речи у предвуковском периоду Велимира Михајловића, доста поуздано лексикографско остварење данас помало заборављеног а знаменитог лингвисте, аутора и другог, комплементарног речника - Посрбице од Орфелина до Вука.

За речник страних речи у предвуковском периоду аутор је ексцерпирао грађу од краја 17. века до 1818. године, и то из штампаних дела, али и архивске грађе, а „корпус обухвата 189 извора, рачунајући и архивске документе, који, сви заједно, чине збир преко 10.000 страница текста" (Михајловић 1972: VII). Аутор, нажалост, нигде није навео ни оквиран број лексема у речнику.

4. О хронологији продора англицизама у српски језик још увек имамо само магловите представе: „Као и свуда у свету, англицизми после 1945. године пристижу све бржим темпом. Док су пре рата заузимали значајније место једино у спорту, сада се нагло множе у речнику забаве и омладинских мода [...], у техници [...] и у многим другим областима" (Клајн 1996: 44). ${ }^{3}$ У Михајловићевом двотомном речнику налази се, помало изненађујуће из перспективе 21. века, свега 25 лексема пореклом из енглеског језика, међу којима има и оних које су стигле немачким посредством, па се - у зависности од одабраног теоријско-методолошког оквира - могу сматрати и германизмима. Такав је нпр. случај са лексемом факторај, први пут регистрованом у тексту из 1816. године, чији склоп сведочи и о енглеском извору (енгл. factory) и о немачком посредству (нем. Faktorei). Сличан је пример и лексема ции, такође са првом потврдом из 1816. године, чији фонетски састав одређује и путању до српског језика: пореклом је из енглеског (chintz), али је у српски ушла из немачког (Zitz).

\footnotetext{
${ }^{3}$ Према истраживањима Милене Јакић, англицизми ни у Речнику САНУ не доминирају бројем међу позајмљеницама, и има их мање од турцизама, латинизама, талијанизама, галицизама и русизама. У обзир ваља, међутим, узети барем два значајна фактора: да су први томови речника почели излазити од 1959. године, дакле управо у време снажнијег продора лексике пореклом из енглеског језика, као и да нису ексцерпирани нпр. бројни часописи посвећени свакодневном животу, забави, модерној култури и супкултури, омладини, спорту и сл., у којима је фреквенција англицизама била и остала врло висока.
} 
Наводимо и остале потврђене англицизме, уз годину прве потврде у Михајловићевом речнику:

аринга (енгл. herring, савр. срп. харинга), 1767.

јутски (енгл. јute, који се односи на јуту, тропску индустријску биљку), 1804.

каурис (енгл. cowrie, „порцулански пуж” који је у неким крајевима Азије

и Африке служио као новац), 1804.

кермес (енгл. kermess, забава, обично добротворна, која се приређује у природи), 1804.

кутерн (енгл. cutter, брза једрилица), 1791.

лард/лорд (енгл. lord, савр. срп. лорд), 1804/1788.

магазин (енгл. magazin, савр. срп. магазин - илустровани часопис), 1768.

манжестер (енгл. Manchester, врста штофа пореклом из Манчестера), 1816. махадони/махагони (енгл. mahagony, савр. срп. махагони), 1816/1804. ${ }^{4}$ милорд (енгл. milord, савр. срп. милорд), 1793.

nаup, пер (енгл. peer, савр. срп. пер - племићка титула), 1809/1804.

пенс (енгл. pence, множина од реnny), 1805.

пудинга (енгл. pudding, савр. срп. пудинг), 1788.

раца (енгл. гаја, савр. срп. раца), 1804.

свита (енгл. sweater, део одела), 1799.

сток (енгл. stock, залиха робе у складишту), 1790.

стокфиш (енгл. stock-fish, бакалар), 1794.

тик (енгл. tick, густа ланена или памучна тканина), 1790.

фармерски (енгл. farmer, савр. срп. фармерски), 1809.

фунт/фунта (енгл. pound, савр. срп. фунта), 1767/1749.

циидер (енгл. cider, савр. срп. цицер и сајдер), 1816.

чип (енгл. chip, савр. срп. чип - жетон, улог), 1794.

5. Наведене лексеме могу се анализирати на више начина. Када се обрати пажња на врсте речи, видљиво је да су готово сви примери именице, и то махом заједничке. Само две лексеме нису именице, и обе су придеви изведени домаћим суфиксом -ски: фармерски (који се односи на фармера), јутски (који се односи на јуту).

Анализа значења првих англицизама указује и на однос између енглеског као језика даваоца и српског као језика примаоца: у наш језик улазе речи које означавају различите локалне титуле (лард/лорд, милорд, раща), монете (каурис, пенс, фунт/фунта), храну и напитке (пудинга, иидер), морске врсте риба (аринга, стокфиш), различите тканине и појмове из (текстилне) индустрије (јута, циц, факторај, манжестер, сток, свита, тик), појмове из културе (кермес, магазин) и напредне војне технике (кутерн), али и мере (фунт/фунта). Број англицизама из области текстилне индустрије недвосмислено доказује да је она у читавој Енглеској, не само у Манчестеру, била високоразвијена и престижна у читавој Европи.

\footnotetext{
${ }^{4}$ Облик махадони може бити и проста штампарска грешка у тексту, али и последица суочавања Димитрија Исаиловића са потпуно непознатом речју коју уводи у српски језик.
} 
Да су неологизми енглеског порекла још увек пролазили кроз процес фонетске и морфолошке адаптације, сведочи више примера међу 25 лексема. Тако је потврђена конкуренција фонетских облика лард и лорд, махадони и махагони, док је штоф из Манчестера именован првобитно као манжестер. Необична финална сугласничка група /-нг/ условила је да именица мушког рода пудинг приђе именицама женског рода са наставком /-a/. ${ }^{5}$ Конкуренцију различитих морфолошких облика примећујемо и код именица мушког и женског рода, фунт : фунта.

Хронолошки низ потврда лексема показује да је први англицизам у Михајловићевом речнику из 1749 , док су последњи из 1816 . године: фунта 1749 , аринга 1767, фунт 1767, магазин 1768, лорд 1788, пудинга 1788 , сток 1790, тик 1790, кутерн 1791, милорд 1793, стокфиш 1794, чип 1794, свита 1799, јутски 1804, каурис 1804, кермес 1804, лард 1804, махагони 1804, пер 1804, раиа 1804, пенс 1805, паир 1809, фармерски 1809, манжестер 1816, махадони 1816, факторај 1816, цидер 1816, ции 1816.

6. Иако обимна и разноврсна, грађа за Михајловићев речник ипак је била ограничена, па ни сам речник не даје потпуну слику, већ само скицу механизама и путева продора лексичких англицизама у некадашњи српски језик. На пример, већ и летимичан преглед само Новина српских Димитрија Давидовића и Димитрија Фрушића, које су излазиле у Бечу од 1813. до 1822. године (Милановић 2015), показује да су се у језику тадашњих српских новина и других јавних гласила појављивали и бројни други англицизми, који нису потврђени у Михајловићевом речнику. Томе је директно доприносило и преузимање тј. превођење вести из тадашњих енглеских дневних новина и часописа, о чему постоје експлицитне потврде у Давидовићевом и Фрушићевом гласилу.

Коначно разрешење свих недоумица везаних за прве англицизме у српском језику понудиће лексикографски пројекти започети у Матици српској, а то су дијахронијски речници на које су у српској култури дуго чека-Историјски речник српског језика (под руководством Јасмине Грковић-Мејџор) и Речник славеносрпског језика (под руководством Исидоре Бјелаковић). ${ }^{6}$ Док ћемо у првом речнику наћи потврде за англицизме у текстовима писаним народним језиком, други ће их потврдити у текстовима насталим на књижевном језику у славеносрпској и доситејевској епохи. Ваља очекивати да ће на основу грађе у њима бити могуће израдити и речник првих англицизама у српском језику, са много више одредница и потврда у различитим стиловима и реченичним контекстима, што ће омогућити и прецизније закључке, за које је Михајловићев речник дао само прве, али доста поуздане смернице.

\footnotetext{
${ }^{5}$ УП. и народски облик бициикла у односу на првобитни облик бицикл.

${ }^{6}$ У Матици српској објављена је ове године огледна свеска Речника славеносрпског језика (РCJ 2017).
} 


\section{ИЗВОРИ}

Михајловић 1972: Велимир Михајловић, Грађа за речник страних речи y предвуковском периоду, I том (А - Љ), Нови Сад: Институт за лингвистику у Новом Саду.

Михајловић 1974: Велимир Михајловић, Грађа за речник страних речи y предвуковском периоду, II том (М - Ш), Нови Сад: Институт за лингвистику у Новом Саду.

\section{ЛИТЕРАТУРА}

Ивић 1998: Павле Ивић, Преглед историје српског језика, Сремски Карловци - Нови Сад: Издавачка књижарница Зорана Стојановића.

Клајн 1996: Иван Клајн, „Лексика”, у: Српски језик на крају века (редактор Милорад Радовановић), Београд: Институт за српски језик САНУ и Службени гласник, 37-86.

Клајн/Шипка 2008: Иван Клајн и Милан Шипка, Велики речник страних речи и израза, Нови Сад: Прометеј.

Милановић 2010: Александар Милановић, Кратка историја српског књижевног језика, Београд: Завод за уџбенике и наставна средства.

Милановић 2013: Александар Милановић, Језик весма полезан, Београд: Друштво за српски језик и књижевност Србије.

Милановић 2015: Александар Милановић, „Језик и стил Новина Сербских (1813-1822)", Предавања 4 / Семинар српског језика, књижевности и културе, Београд: Међународни славистички центар, 111-119.

Павић 1979: Милорад Павић, Историја српске књижевности класицизма и предромантизма: Класицизам, Београд: Нолит.

Павић 1983: Рађање нове српске књижевности, Београд: Српска књижевна задруга.

Павић 1985: Милорад Павић, Историја, сталеж и стил, Нови Сад: Матица српска.

PCJ 2017: Речник славеносрпског језика : огледна свеска (прир. Исидора Бјелаковић, Ирена Цветковић Теофиловић и Александар Милановић), Нови Сад: Матица српска.

Толстој 2004: Никита И. Толстој, Студије и чланщи из историје српског књижевног језика, Београд - Нови Сад: Завод за уџбенике и наставна средства - Вукова задужбина - Матица српска.

Унбегаун 1995: Борис Унбегаун, Почеии књижевног језика код Срба, Београд - Нови Сад: Вукова задужбина - Матица српска - Орфелин. 